\title{
Sources of Investment Support of Production and Business Activities in the Russian Economy
}

\author{
A.V. Streltsov ${ }^{1}$, G. I.Yakovlev ${ }^{1, *}$, and I.V. Kosyakova ${ }^{2}$ \\ ${ }^{1}$ Samara State University of Economics, Samara, Russia \\ ${ }^{2}$ Samara State Technical University, Samara, Russia
}

\begin{abstract}
The problems of determining effective and available sources of investment for the purposes of technical and organizational development of enterprises and business activities are studied. An urgent requirement is to reverse the unstable dynamics of the industrial investments volumes implemented by Russian enterprises, the low degree of renewal of fixed assets of enterprises that go to a critically high level of wear and tear, which does not allow for high resource productivity and competitiveness of Russian enterprises of processing activities in the world market. The purpose of the study is to consider the indicators of the current state and the possibility of using certain available sources of investment in production, to analyze the characteristics of state regulation of investment activity in the economy. The article uses methods of statistical grouping, analysis of cause-and-effect relations, and meaningful economic interpretation of the phenomena of the investment process in the Russian and world economy conditions. A comparative analysis of the most popular sources of investment support for production and economic activities of enterprises is carried out, their advantages and disadvantages, and features of use are shown. As a result, recommendations were formed on the choice of investment sources in relation to various economically stable groups of manufacturing enterprises operating in markets of different regulatory severity.
\end{abstract}

Keywords: sources, investment, enterprises, business activity, competitiveness, development.

\section{Introduction}

Enterprises need various funds to carry out their production and sales activities, which are in practice mobilized from the totality of all available investment resources. Currently, in the context of the global socio-economic crisis caused by the ongoing viral pandemic, the growth of global uncertainties, trade and economic wars, and other adverse, restrictive factors, the economic authorities of many countries have begun to develop a national plan for economic recovery, identifying and attracting investment necessary for the development of productive forces, corresponding to the required size and sources. For the development of the scientific and industrial sector in Russia, it is important that the national plan for

*Corresponding author: dmms7@rambler.ru 
long-term economic development contains not only measures to support individual industries, but also includes the development of end-to-end technologies, such as industrial Internet, robotics, radio electronics, automated production, etc.

It is clear that the absence of any well-thought-out policy regarding the development of productive forces, given the chronic underinvestment, expensive financial resources for enterprises of processing activities, with their current low efficiency and productivity, carrying out production on obsolete equipment, with periodically recurring crises, has led to the destruction and instability of many of them. This is especially noticeable in non-primary processing economic activities, primarily in mechanical engineering, which integrates advanced scientific and technological achievements.

\section{Methodology}

In this study, the authors rely mainly on the theoretical provisions of the production approach in the study of the content and process of industrial investment. They, according to the methodology of J. M. Keynes, have an exclusively industrial origin, while the income from the sale of products and services of the enterprise is divided into two components consumption and investment. Despite the priority of the manufacturing sector over the financial sector, this approach does not deny the role of credit for business development, which is balanced by the obligations of industrial enterprises on the scale of the macroeconomy.

This approach allows for various classifications of industrial investments in the study of enterprise development problems. As a rule, specialists distinguish internal and external sources of investment, according to Fig. 1. The first include retained earnings and depreciation. This includes a number of other less significant and stable components: investments of citizens and legal entities' money, unused part of social funds, etc. External loans include various forms of lending by commercial entities, government loans, funds raised on the stock market (consolidated funds for issuing shares, bonds, issuing bills, etc.). These sources of investment can be defined as traditional, widely used in a market economy. In addition, among the external ones, we can distinguish so-called "nontraditional" ones, which are less often used in enterprises, but have significant investment potential. These include leasing operations, cooperative interaction of enterprises, financial relations between subsidiaries and parent companies within the framework of international strategic alliances, etc. 


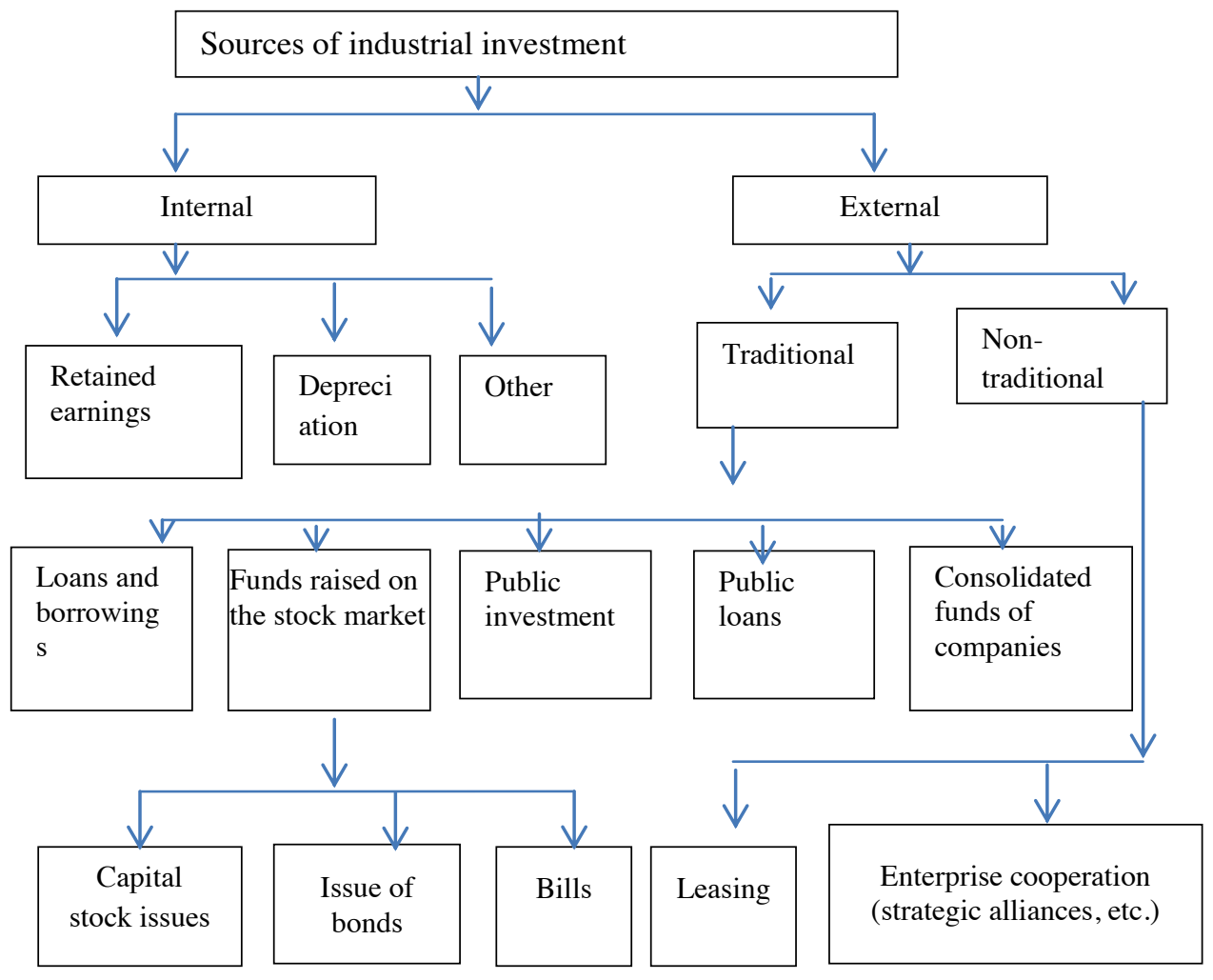

Fig. 1. Composition of investment sources of industrial enterprises Source: Own processing.

Describing the resource capabilities of these forms of investment in relation to the subjects of the domestic Russian economy, we should note the following. The most significant source of own funds in machine-building enterprises is depreciation deductions, i.e. annual (monthly) deductions in proportion to the worn-out part of the fixed assets cost. However at present the use of depreciation for the purpose of updating the worn out elements of fixed assets is extremely insufficient and is limited by the following reasons:

1) Lack of incentives for targeted use of depreciation;

2) Using primarily the straight-line method of calculation;

3) Rather large actual rates of depreciation of the cost of cash in the case of their accumulation in the depreciation fund;

4) Insufficient motivation for updating fixed assets in general, since the current financial condition of many enterprises requires the immediate use of available funds, while the same unfavorable financial condition of consumers forces them to accept low-quality, but relatively cheap products.

We used methods of statistical grouping, comparative analysis, and meaningful economic interpretation of economic practice at the macro and micro levels. Experimental base of the study: results of activities of Russian and foreign enterprises in various industries, management bodies of national economies, especially in the formation and promotion of targeted industrial policy. 


\section{Results}

The formation of future national champions in the production of innovative products and business activities which should be competitive on the international market. This formation requires a well-thought-out industrial policy and large-scale investment resources. However, the results of investment activity of domestic economic entities over the past nine years have been quite modest (Table 1).

Table 1. Key indicators of investment activity in the Russian economy

\begin{tabular}{|l|l|l|l|l|l|l|}
\hline Indicator & Units & 2010 & 2015 & 2016 & 2017 & 2018 \\
\hline $\begin{array}{l}\text { Investment in fixed } \\
\text { assets: }\end{array}$ & billion rubles & 9152.1 & 13897.2 & 14748.8 & 16027.3 & 17595.0 \\
\hline per capita, & thousand rubles & 64.1 & 94.9 & 100.6 & 109.1 & 119.8 \\
\hline $\begin{array}{l}\text { as a percentage of the } \\
\text { previous year }\end{array}$ & $\begin{array}{l}\text { (in comparable } \\
\text { prices) }\end{array}$ & 106.3 & 89.9 & 99.8 & 104.8 & 104.3 \\
\hline $\begin{array}{l}\text { as a percentage of gross } \\
\text { domestic product }\end{array}$ & $\%$ & 20.7 & 20.0 & 21.2 & 21.5 & 20.7 \\
\hline Depreciation of fixed assets & $\begin{array}{l}\text { at the end of the } \\
\text { year,percent }\end{array}$ & 47.1 & 47.7 & 48.1 & 47.3 & 46.6 \\
\hline $\begin{array}{l}\text { Coefficient of renewal of } \\
\text { fixed assets }\end{array}$ & $\begin{array}{l}\text { in constant prices, } \\
\text { percent }\end{array}$ & 3.7 & 3.9 & 4.4 & 4.3 & 5.1 \\
\hline
\end{tabular}

Source: Own processing according to the Rosstat data of the Russian Federation [6].

The analysis of these tables shows quite unstable dynamics of investments implemented by Russian enterprises. Despite the fact that the degree of depreciation of fixed assets of enterprises in the vast majority is already approaching 50\%, the coefficient of their renewal only slightly exceeds 5 percent. At this rate, the full renewal of fixed assets can only occur in twenty years, when the organizational and technical apparatus of production will be repeatedly changed throughout the world in accordance with the laws of changing technical patterns and cycles of modernization. In addition, outdated production capacities of domestic industrial enterprises will not be able to effectively support the digital transformation, increase the productivity of resources to the level of world-leading firms, thereby losing in ensuring the international competitiveness of their products.

In addition to depreciation, another important internal source of investment is the portion of net profit allocated for the accumulation purposes. In a number of large organizations, this can be quite a significant amount. However, in general, given the low level of profitability in the manufacturing industry and the need for funds to update fixed assets, it can be noted that this source of investment is an extremely small amount in comparison with the necessary need.

Moreover, considering the complex characteristics of the investment processes of security capital renewals, including, in addition to the above, this is an orientation when updating mainly on imported equipment and the low exchange rate of the domestic currency, significantly increasing the cost of procuring from abroad equipment and technological backwardness of the majority of enterprises, in addition to requiring new equipment to raise funds for the purchase of new technologies and corporate services, again mainly foreign, and generally continued for a fairly long period insufficient economic activity and lack of meaningful economic growth. All this determines the extremely low value and common set of internal sources - net profit and depreciation. In this regard, the role of using external sources, including borrowed ones, is increasing.

Leasing transactions can also be defined as a specific source of investment. Their specificity lies in the fact that the content of leasing is the provision of property for rent. 
However, the income received by the leasing company is in the form of a certain percentage. Leasing companies are very closely connected with financial organizations (banks). A special feature of leasing operations is that they can not be considered as a source of investment for capital renovation of the enterprise. They are usually intended to financing the purchase of individual machines and units, most often transport vehicles. In modern conditions, state loans, direct state investment, as well as consolidated funds of integrated companies have become important for certain categories of machine-building enterprises. Despite their low availability, these sources have a very important characteristic for businesses: low cost and minimal risk compared to other options. However, the ability of enterprises to influence decision-making processes on their involvement is limited.

The possibility of increasing investment activity from the part of non-traditional sources of investment - the international cooperation and integration of enterprises now is quite promising [11, p.466]. Transnational strategic alliances and other forms of integration relations between enterprises of different jurisdictions allow not only to attract investment, but even in their absence, to reduce the overall need for them, reduce risks by dividing the range of works between partners in accordance with taken competencies.

Speaking about the state regulation of investment activity and its impact on the behavior of investors, we can not fail to note its relationship and, accordingly, the need to take into account the specifics of the economic activities of individual sub-sectors and machinebuilding enterprises. First of all, it is determined by the technological features of production and the functioning of the industry commodity market. In accordance with this, we can distinguish the following enlarged groups of enterprises and sub-sectors of mechanical engineering:

1. Oligopolistic sector, which includes enterprises whose target market of goods and services is controlled by large oligopolistic structures;

2. Marketing (market sector), with a market of goods and services based on competition;

3. A depressed sector where the market of goods and services is difficult for domestic enterprises to access for various limiting reasons;

4. The sector of military-industrial complex enterprises, the market of which is determined by the state order and regulated by the state.

Of course, to a certain extent, this division is somewhat conditional, since a diversified enterprise can operate in different markets. However, any enterprise has the main products that occupy the largest range, and the possibilities of production diversification in conditions of lack of investment are significantly limited by the existing technological scheme of production of the enterprise's products. In a number of major sub-sectors of mechanical engineering (automotive, shipbuilding, aerospace, railway engineering, etc.), expanding the production line requires significant time and resources, so that as a result, a diversified enterprise could carry out its activities in various segments of the commodity market.

Describing the enterprises of the oligopolistic sector, it can be noted that for them the possibility of attracting investment is closely linked with the establishment of partnerships with the relevant Russian oligopolies (UAC, USC, Russian Railways, etc.). At the same time, the state task is to coordinate and regulate cooperative relations and form specific projects for the development of machine-building enterprises, which are ultimately aimed at improving the efficiency of oligopolistic structures. Attracting the necessary investments for the implementation of the project should also include the participation of the latter in this process. Therefore, the state has a significant share in the capital of these structures, and its regulatory influence may well ensure an effective level of organization of these cooperative relations. 
Marketing oriented enterprises (market type) are forced to rely mainly on the free market in their activities and, accordingly, form their investment projects more independently, in comparison with the previous type, on a market basis. These projects are significantly more sensitive to macroeconomic indicators, the state of the business environment, and the level of risk. Therefore, enterprises of this type are most dependent on various measures of state support.

Enterprises in the depressed sector of the economy, as a rule, can not independently ensure the proper level of efficiency of their investment projects, since the introduction of new products to the market for them is limited for various reasons. For example, because the market is busy with imported products or there are special technical requirements. In order to increase the investment activity of enterprises in this group, it is necessary to develop a comprehensive program for the development of sub-sectors based on restructuring, by creating large integrated holding companies, and organizing import substitution.

Investment activities of military-industrial complex enterprises are mainly regulated by the state. To bring it to a different qualitative level within the framework of state regulation, it is necessary not only to ensure and control the implementation of the state order, but also to set tasks and monitor their implementation for the diversification and development of production, which is also noted in the work of D. A. Nikolaev, who has considered in detail alternative existing and promising sources of financing for enterprises of the militaryindustrial complex [10, p.107].

\section{Discussion}

In most of the works of specialists, the prospects for investment support of enterprises and business activities are linked to the solution of problems of effective use of depreciation charges. Thus, Eroshevsky S. A. (2010) and co-authors considered the financial features of depreciation as a source of investment in the development of the production potential of an oil and gas producing enterprise [3, p.120]. Jodi L.Gissel (2016) notes that targeted reproduction of depreciation charges can provide a significant part of the financing of the costs of modernization of the enterprise [7, p.61].

Improving the efficiency of the depreciation process at enterprises requires the development and implementation of a targeted set of measures, the leading of which are legislative and tax measures. Miklyaeva Yu. S. supports a similar interpretation, noting the importance of depreciation in financing the reproduction of fixed assets in relation to enterprises in the oil refining industry [9, p.227].

However, among scientists-economists, mainly financial and accounting specialization, the view that depreciation should not be the main source of investment is becoming more widespread. It is no coincidence that Kurmakaeva E. Sh. (2006), considering the possibility of involving additional sources of financing in the system of reproduction of the fixed capital of Russian enterprises, focuses on the development of leasing relations, provided that appropriate favorable conditions are created for its development at the macroeconomic level [8, p.176].

Fedorov Yu. V. et al. (2016) identified the problems of insufficient investment level in the fixed capital of machine-building enterprises and incomplete use of the potential of external sources of capital investment financing. They suggested to strengthen the role of attracted and borrowed funds as sources of investment financing in the modernization and renewal of the fixed capital of machine-building enterprises [4, p.7].

Efimychev Yu. I. and co-authors (2012) analyzed the sources and volumes of financing of domestic enterprises at the stages of designing and putting products on the market with the participation of the state, business angels, and venture funds[2, p.239]. Vivek Ghosal 
and Usha Nair-Reichert (2009) examined the relationship of sources, mechanisms and financial instruments for attracting investment in the innovative activity of an industrial enterprise, conducted a comparative analysis of the most popular sources of attracting investment, with an assessment of advantages and disadvantages[14, p.536].

Rubtsova Yu. A. considered external sources of investment for enterprises, advantages and disadvantages of IPO as a source of investment financing for enterprises[12, p.431]. Gurieva I. V. (2014) analyzed the existing theoretical and practical approaches, procedures and algorithms for selecting sources of investment financing in the scientific economic literature and identified the minimum price of sources of financing, depending on the economic conditions, financial condition, goals and objectives of the enterprise that it solves as the main criterion[5, p.271].

Sotnikova L. N. and Kukush L. I. (2016) studied the main problems of selecting sources of financing for real investment projects by comparing the cost of attracting them for the enterprise and identified the main factors of pricing sources of real investment financing in enterprises [13, p.16]. With regard to investment problems, Dimitris Skuras et al. note that the size of a firm has a direct, inverted U-shaped influence on the probability of investment and an indirect influence through the linear influence of the size on the probability of innovation [1, p.1778]. Yuan Hu (2012) uses the example of Chinese enterprises to link investment in fixed assets with a contribution to reducing energy consumption, directed to improve energy efficiency of new investment projects in the field of fixed assets formation $[15, \mathrm{p} .327]$.

As a result, a brief comparative description of the sources of investment for the development of the enterprise is presented in Table 2.

Table 2. Comparative characteristics of investment sources for modernization of machine-building enterprises

\begin{tabular}{|c|c|c|c|c|c|}
\hline \multicolumn{2}{|c|}{ Sources of investment } & \multicolumn{4}{|c|}{ Characteristics } \\
\hline № & Name of the source & $\begin{array}{c}\text { Possibility of } \\
\text { using }\end{array}$ & Value & Cost & Riskiness \\
\hline 1. & Profit & Max & Min & Low & Min \\
\hline 2. & Depreciation & $\begin{array}{c}\text { Changes } \\
\text { depending on the } \\
\text { start time of } \\
\text { mobilization }\end{array}$ & Low & Min \\
\hline 3. & $\begin{array}{c}\text { Government loans } \\
\text { and public } \\
\text { investments }\end{array}$ & Min & Max & Low & Min \\
\hline 5. & $\begin{array}{c}\text { Commercial loans } \\
\text { and borrowings }\end{array}$ & Average & Max & Migh & Low \\
\hline 6. & $\begin{array}{c}\text { Issue of shares } \\
\text { management } \\
\text { company of the }\end{array}$ & $\begin{array}{c}\text { Limited (for a } \\
\text { of enterprises) }\end{array}$ & $\begin{array}{c}\text { Average (limited } \\
\text { by the capital } \\
\text { ownership } \\
\text { structure) }\end{array}$ & Low & Max \\
\hline 7. & $\begin{array}{c}\text { Strategic alliance } \\
8 .\end{array}$ & Min & $\begin{array}{c}\text { Average (limited } \\
\text { by the capital } \\
\text { ownership } \\
\text { structure) }\end{array}$ & High & Max \\
\hline & Leasing & Average & Min & Low & Average \\
\hline
\end{tabular}

Source: Own processing. 
This table describes the main characteristics of individual sources of industrial investment for the machine-building complex. This is determined by the number of generated estimates. For example, the possibility of using such a source of investment as "commercial loans" is estimated as average, although the banking sector's opportunities for financing seem to be maximum. However, in most domestic machine-building enterprises, the level of profitability of production is lower than the existing interest rate, which makes it difficult to attract loans.

\section{Conclusion}

Development and modernization is an integral stage of the life cycle of enterprise development and business structures. An urgent need for investment resources for its implementation occurs just when the financial and economic indicators of its activities deteriorate, and the investment attractiveness is minimal. The current order of financial relations in modern regulatory and methodological accounting and tax documents does not link depreciation with the need to create funds, reserves for updating fixed assets. It is no accident that many economists suggest making changes to the concept of accounting and ensuring the targeted reproduction use of depreciation charges. It is obvious that they are able to provide a significant part of the financing costs for the modernization of the enterprise. It should also be noted that it is the targeted use of depreciation for updating fixed assets that distinguishes the historical periods of our country, in which the development of industry was the most dynamic.

The investment justification of the technical and organizational development of an enterprise is largely influenced by both the characteristics of manufacturing enterprises and the specific characteristics of its current state. The most affordable and reliable sources of investment for enterprise modernization are profit and depreciation. The latter, as the practice of industrialized countries shows, can make a significant share in the investment justification for enterprise modernization. However, to achieve this in relation to the Russian business environment, it is necessary to implement a set of legislative and regulatory measures to improve the standards of accounting, tax accounting and planning.

\section{References}

1. D. Skuras, K. Tsegenidi, K. Tsekouras. Product innovation and the decision to invest in fixed capital assets: Evidence from an SME survey in six European Union member states. Research Policy, 37(10), pp. 1778-1789. Available at: https://doi.org/10.1016/j.respol.2008.08.013 (2008)

2. Yu. I. Efimychev, Yu. O. Plekhova, A.V.Volkov. Analysis of sources and volumes of investment in domestic innovative enterprises. No.: 1-1, 2012, P.: 239-243Bulletin of the National Research Lobachevsky State University of Nizhni Novgorod. №:1-1, P.: 239-243 (2012)

3. S. A. Eroshevsky, A.V.Streltsov, K. A. Kalugina, T. S. Muravyova. Depreciation as a source of investment in the development of the production potential of an oil and gas producing enterprise. Problems of improving the organization of production and management of industrial enterprises: Intercollegiate collection of scientific papers.. Publishing house: Samara State University of Economics (Samara) №: 1-1, P.: 120124.(2010)

4. Yu. V. Fedorov, O. A. Druzhkova. Analysis of investment in fixed assets and sources of their financing for machine-building enterprises. Socio-economic management: 
theory and practice.. Publishing house: Izhevsk State Technical University University (Izhevsk) №:1(28), P. 4-12. (2016)

5. I. V. Gurieva Justification of the procedure for selecting sources of financing for investment in technical re-equipment of the enterprise Business inform. Publishing house: Research center of industrial development problems of the National Academy of Sciences of Ukraine (Kharkiv) № 3, P. 271-275 (2014)

6. Investment in Russia. 2019: Stat. sb. Rosstat. - M., 228 p. (2019)

7. Jodi L. Gissel. A case of fixed asset accounting: Initial and subsequent measurement. Journal of Accounting Education 37, pp. 61-66. Available at: https://doi.org/10.1016/j.jaccedu.2016.10.001 . (2016)

8. E. Sh. Kurmakaeva Additional sources of investment in the system of reproduction of fixed capital of enterprises. Bulletin of the State Technical University of Saratov. 3(14), P. 176-180 (2006)

9. Yu. S. Miklyaeva Depreciation deductions as a source of investment in fixed assets of oil refining enterprisesScience of the XXI century: current directions of development. Publishing house of Samara State University of Economics (Samara) № 1-2, P. 227 230 (2017)

10. D. A. Nikolayev Sources of investment in enterprises of the military-industrial complex in modern economic conditions. Socio-economic and technical problems of the military-industrial complex: history, reality, innovations.. Interuniversity Collected papers on materials of V All-Russian scientific practical conference. 2018. Publishing house: Nizhny Novgorod State Technical University (Nizhny Novgorod) P.: 107-110 (2018)

11. E.M. Pimenova, A.V. Streltsov, G.I. Yakovlev. Development of International Production Cooperative Relations in the Digital Economy // Lecture Notes in Networks and Systems. - 84. - pp. 466-472. DOI: 10.1007/978-3-030-27015-5_56. URL: https://www.scopus.com/inward/record.uri?eid=2-s2.0$85070224756 \&$ doi $=10.1007 \% 2 \mathrm{f} 978-3-030-27015-$ 5_56\&partnerID=40\&md5=2764581e4c8f601bd1 fef916eda9b52c (2020)

12. Yu. Rubtsova A.Capital issues are a source of investment financing for enterprises. Topical issues of economic sciences, (2) P. 431-435. (2008)

13. L. N. Sotnikova, L. I. Kukush. Comparison of prices of various financing sources of real investment in the enterprise. Financial Bulletin. Publishing house: Voronezh State Agrarian University named after Emperor Peter I (Voronezh). 4(35), P. 16-23. (2016)

14. V. Ghosal, U. Nair-Reichert. Investments in modernization, innovation and gains in productivity: Evidence from firms in the global paper industry. Research Policy. 38(3), P. 536-547. Available at: https://doi.org/10.1016/j.respol.2008.10.010. (2009)

15. Y. Hu. Energy conservation assessment of fixed-asset investment projects: An attempt to improve energy efficiency in China. Energy Policy, 43, pp. 327-334. Available at: https://doi.org/10.1016/j.enpol.2012.01.009. (2012) 